\title{
Paira Chickpea under Rice Fallow in Lowland Ecosystem of West Bengal, India
}

\author{
Hedayetullah MD ${ }^{1 *}$, Arnob Roy Chowdhury², Mainak Ghosh ${ }^{2}$, Kali Krishna Hazra ${ }^{3}$, Chaitanyo Prasad Nath ${ }^{3}$, \\ Raghunath Sadhukhan ${ }^{1}$ and Parveen Zaman ${ }^{4}$
}

${ }^{1}$ AICRP on Chickpea, Directorate of Research, Bidhan Chandra Krishi Viswavidyalaya, India

${ }^{2}$ Department of Agronomy, Bihar Agriculture University, Sabour India

${ }^{3}$ Crop Production Division, Indian Institute of Pulses Research, India

${ }^{4}$ Assistant Director of Agriculture, Pulse and Oilseed Research Sub-Station, India

Submission: October 01, 2017; Published: January 08, 2018

"Corresponding author: Hedayetullah MD, AICRP on Chickpea, Directorate of Research, Bidhan Chandra Krishi Viswavidyalaya, Kalyani, Nadia, West Bengal, Pin-741235, India, Email: hedaye.bckv@gmail.com

Abstract

Paira crop is sown before harvesting of the main crops. Paira cropping is followed where rice is harvested in late with high soil moisture and water is scarcity to save the chickpea at later stage. To avoid these unavoidable circumstances agronomic strategies is urgent need for increasing cultivated area in fallow areas of West Bengal which was not followed earlier. There have ample scope horizontal expansion of fallow area with chickpea to maintain soil health, less use of water, sustainability and profitability.

Keywords: Paira chickpea; Rice fallow; Agronomic strategies; Production

\section{Opinion}

Paira cropping is sowing of second crop before harvesting of the main crops (Rice). Paira (Relay) cropping is followed where late transplanting long duration rice harvested in late with high soil saturation and water is scarcity to save the second crop at a later stage. Due to high soil saturation during rice harvesting, fields take another 15 to 20 days for proper soil moisture for sowing of second crop in low to medium land ecosystem of West Bengal. The strategies have to adopt for utilization of vast fallow land in low to medium land. In conventional agriculture, farmers keep fallow the land instead of second crop. In some areas Paira cropping of grass pea and lentil is followed under rice fallow situation after harvesting of rice in residual soil moisture but chickpea also possible in low to medium land ecosystem [1].

The strategies for cultivation of Paira chickpea have to understand in new dimension for higher production. From starting to harvesting and before sowing of chickpea crop in standing crop is very much crucial for germination of the seed. In standing rice crop, soil moisture has to check for proper germination. The rice crop field should be well levelled for maintaining soil moisture in uniform mode in which uniform soil moisture can obtained, it facilitates uniform germination of seed. The planting geometry of rice crop also plays an important role for higher production of succeeding Paira chickpea crop. Machine transplanting or line transplanting rice crops gives higher yield itself rather it also gives higher yield of second crop. During sowing of chickpea it facilitates to germination, proper establishment and minimal disturbance of chickpea crop during harvesting of rice crop [2]. In Paira cropping system land are not prepared only under wet soil seed are sown. For any deviation in maintaining levelled land and uniform soil moisture germination of the crop may hamper. In low to medium land soil characterised by clay loam soil with high water holding capacity is suitable for chickpea crop period. The residual soil moisture of this soil is sufficient for chickpea plant growth and development [3].

Before sowing, seed should be treated with fungicides followed by rhizobium and trichoderma inoculation for disease free plant and better nodulation. The seed should be treated with fungicides bavistin @2g/kg seed at least seven days before rhizibium and trichoderma inoculation @20g/kg seed with suitable strain. The disease-resistant varieties of chickpea are 
more suitable to control root rot and blight in Paira cropping situation. The seed is broadcast at the rate of 100 to $120 \mathrm{~kg} / \mathrm{ha}$, $20-25 \%$ higher seed rate of recommended seed rate. To control soil borne pathogen liquid formulation of tricoderma may spray in wet soil. Manual one or two hand weeding is followed at 25 to 30 days or 45 to 50 days after sowing depending upon weed seed bank to control broad spectrum of weed.

Fertilization is not possible under Paira cropping system. Under nutrient stress condition nutrient solution like urea and DAP at the rate $2 \%$ is foliar sprayed at vegetative stage or before flowering. Insect-pests are control through application of pesticides according to types of pest for effectiveness. Mostly pod borer (Helicoverpa armigera) at branching and pod development stage is infested more.

Therefore, these agronomic strategies are very much urgent now a day because slogan like "More Crop per Drop" is giving message to us that use less water for production of crop. With this light residual soil moisture utilization in second crop and time bound agronomic management for proper natural resource utilization.

\section{References}

1. Bitew Y, Asargew F (2014) Rice (Oryza sativa) and chickpea (Cicer arietinum L.) relay intercropping systems in an additive series experiment in rain fed lowland ecosystem of Fogera vertisols. Science Research 2(6): 179-184.

2. Mahmood A, Hussain AFH, Ali A (2003) Rice planting geometry facilitating relay cropping at zero tillage. International journal of agriculture \& biology 15(4): 435-437.

3. Pande S, Sharma M, Ghosh R, Rao SK, Sharma RN, et al. (2012) Opportunities for chickpea production in rainfed rice-fallows of India-Baseline survey report. International Crops Research Institute for the Semi-Arid Tropics Patancheru 502 324, Andhra Pradesh, India, p. 56.

\begin{tabular}{|l|}
\hline \multicolumn{1}{|c|}{ Your next submission with Juniper Publishers } \\
will reach you the below assets \\
- Quality Editorial service \\
- Swift Peer Review \\
- Reprints availability \\
- E-prints Service \\
- Manuscript Podcast for convenient understanding \\
- Global attainment for your research \\
- Manuscript accessibility in different formats \\
( Pdf, E-pub, Full Text, Audio) \\
- Unceasing customer service \\
Track the below URL for one-step submission \\
https://juniperpublishers.com/online-submission.php \\
\hline
\end{tabular}

